\title{
KONSENTRASI DAN STATUS MUTU LOGAM BERAT DALAM AIR DAN SEDIMEN DI KAWASAN PESISIR KABUPATEN KEPULAUAN SANGIHE
}

\section{CONCENTRATION AND QUALITY STATUS OF HEAVY METALS IN THE COASTAL WATERS AND SEDIMENT OF SANGIHE ISLANDS REGENCY}

\author{
Akhmad Mustafa ${ }^{1}$, Ruzkiah Asaf ${ }^{1}$, Kamariah $^{1}$, \& I Nyoman Radiarta ${ }^{2}$ \\ ${ }^{1}$ Balai Riset Perikanan Budidaya Air Payau dan Penyuluhan Perikanan, Maros, 90512, Indonesia \\ ${ }^{2}$ Pusat Riset Perikanan, Jakarta Utara, 14430, Indonesia \\ "E-mail: akhmadmustafa@yahoo.com
}

\begin{abstract}
It is feared that the metal mineral exploration could lead to mining waste in the form of heavy metals that pollute water and sediments in the coastal areas of Sangihe Islands Regency, North Sulawesi Province. The objective of this research was to investigate the concentration and quality status of heavy metals inside the water and sediment with regard to possibility of potential pollutants at the mariculture existing and potential sites. The research was carried out in coastal areas of Bays of Talengan, Manalu, and Dagho and surrounding areas by sampling of water and sediments and then analyzed in the laboratory for heavy metals of $\mathrm{Cu}, \mathrm{Fe}, \mathrm{Hg}, \mathrm{Pb}$, and $\mathrm{Zn}$. Descriptive statistics were used to analyze existing data and then used Storet (Storage and Retrieval) method to determine the quality status of water and sediment of heavy metals for marine organisms. The results showed that from 5 heavy metals analyzed in water and sediment were found 4 of them i.e. $\mathrm{Cu}, \mathrm{Fe}, \mathrm{Pb}$, and $\mathrm{Zn}$ were detected and 1 other was undetected i.e. Hg in the coastal areas of Sangihe Islands Regency. Results of quality status determination of water and sediment indicate that water of coastal areas of Sangihe Islands Regency was classified as heavily polluted from heavy metals of $\mathrm{Cu}$ and $\mathrm{Pb}$ for marine organisms, while sediment was classified as an appropriate quality standard of heavy metal for marine organisms. Concentrations of heavy metals of $\mathrm{Cu}$ and $\mathrm{Pb}$ inside the water have exceeded the heavy metal quality standard for marine organisms.
\end{abstract}

Keywords: heavy metal, quality status, Sangihe Islands, sediment, water

\begin{abstract}
ABSTRAK
Eksplorasi mineral logam tertentu dikhawatirkan dapat menyebabkan adanya limbah tambang berupa logam berat yang mencemari air dan sedimen di kawasan pesisir Kabupaten Kepulauan Sangihe, Provinsi Sulawesi Utara. Penelitian ini bertujuan untuk mengetahui konsentrasi dan status mutu logam berat dalam air dan sedimen sehubungan dengan potensi pencemaran yang mungkin terjadi dalam hubungannya dengan pengembangan marikultur. Penelitian dilaksanakan di kawasan pesisir Teluk Talengan, Manalu, dan Dagho dan sekitarnya dengan mengambil sampel air dan sedimen dan selanjutnya dianalisis di laboratorium untuk logam berat $\mathrm{Cu}, \mathrm{Fe}, \mathrm{Hg}, \mathrm{Pb}$, dan $\mathrm{Zn}$. Statistik deskriptif digunakan untuk menganalisis data yang ada dan selanjutnya metode Storet (Storage and Retrieval) digunakan untuk menentukan status mutu air dan sedimen dari logam berat untuk biota laut. Hasil penelitian menunjukkan bahwa dari lima logam berat yang dianalisis dalam air dan sedimen, dijumpai satu di antaranya $\mathrm{Hg}$ yang tidak terdeteksi di kawasan pesisir Kabupaten Kepulauan Sangihe. Hasil penentuan status mutu air dan sedimen menunjukkan bahwa air di kawasan pesisir Kabupaten Kepulauan Sangihe tergolong tercemar berat dari logam berat $\mathrm{Cu}$ dan $\mathrm{Pb}$ untuk biota laut, sedangkan sedimennya tergolong memenuhi baku mutu logam berat untuk biota laut. Konsentrasi logam berat $\mathrm{Cu}$ dan $\mathrm{Pb}$ dalam air telah melampaui baku mutu logam berat untuk biota laut.
\end{abstract}

Kata kunci: air, Kepulauan Sangihe, logam berat, sedimen, status mutu 


\section{PENDAHULUAN}

Berdasarkan Undang-Undang Nomor 1 Tahun 2014 tentang Pengelolaan Wilayah Pesisir dan Pulau-Pulau Kecil dinyatakan bahwa Pulau-Pulau Kecil Terluar ditetapkan sebagai Kawasan Strategis Nasional Tertentu yang memiliki potensi sumberdaya alam dan jasa lingkungan yang tinggi serta memiliki peran yang sangat strategis dalam menjaga kedaulatan Negara Kesatuan Republik Indonesia. Sebelumnya pulau-pulau terdepan tersebut dikenal sebagai pulau-pulau terluar. Pemerintah menerbitkan Keputusan Menteri Kelautan dan Perikanan Nomor 12/KEPMEN-KP/2015 tentang Tim Percepatan Investasi di Bidang Kelautan dan Perikanan untuk lima pulau terdepan: Pulau Simeulue (Nanggroe Aceh Darussalam), Pulau Natuna (Kepulauan Riau), Pulau Sangihe (Sulawesi Utara), Saumlaki (Maluku) dan Merauke (Papua).

Kabupaten Kepulauan Sangihe terdiri atas gugusan pulau besar dan kecil berjumlah 105 pulau (3 pulau diantaranya sebagai pulau-pulau terluar) dan memiliki garis pantai mencapai sekitar $297 \mathrm{~km}$, serta memiliki sumberdaya alam berupa lautan yang sangat besar (BPS, 2014). Kondisi demikian memerlukan penyesuaian fokus pembangunan melalui pemanfaatan potensi sumberdaya laut dan pesisir berupa budi daya laut atau marikultur. Kabupaten ini memiliki sumberdaya laut dan juga memiliki sumberdaya alam berupa daratan dengan berbagai potensi bahan tambang. Bahan tambang berupa logam mineral yang dijumpai di Kabupaten Kepulauan Sangihe adalah: emas $(\mathrm{Au})$, barit $\left(\mathrm{BaSO}_{4}\right)$, pirit $\left(\mathrm{FeS}_{2}\right)$, hematit $\left(\mathrm{Fe}_{2} \mathrm{O}_{3}\right)$, pasir dan biji besi $(\mathrm{Fe})$, dan malahatit $\left(\mathrm{CuCO}_{3} \mathrm{Cu}(\mathrm{OH})_{2}\right)$ (BPS, 2014). Eksplorasi mineral logam tersebut dikhawatirkan dapat menyebabkan adanya limbah tambang berupa logam berat yang mencemari air dan sedimen di kawasan pesisir. Dilaporkan bahwa telah dilakukan eksplorasi terhadap tambang emas baik yang memiliki izin maupun Pertambangan Emas
Tanpa Izin (PETI) di Kabupaten Kepulauan Sangihe yang menyebabkan dampak negatif di lingkungan sekitarnya, termasuk di kawasan pesisir (Makagansa, 2013; Tamon, 2013). Limbah dari tambang emas dapat menjadi pencemar logam berat merkuri atau raksa $(\mathrm{Hg})$, timah hitam atau timbal $(\mathrm{Pb})$, tembaga $(\mathrm{Cu})$, seng $(\mathrm{Zn})$, dan besi $(\mathrm{Fe})$ (Biney et al., 1994). Keberadaan logam berat di kawasan pesisir, selain dapat berasal dari pertambangan, juga dapat berasal dari berbagai macam jenis industri, rumah tangga, dan limbah pertanian. Distribusi logam berat dalam air dan sedimen memainkan peran kunci dalam mendeteksi sumber pencemaran logam berat di ekosistem perairan (Förstner \& Wittmann, 1981; Samad et al., 2015; Anbuselvan et al., 2018). Endapan sistem air tercemar, termasuk logam berat, dapat menyebabkan peningkatan konsentrasi dalam sedimen yang menyebabkan toksisitas potensial bagi organisme akuatik (Heyvart et al., 2000; Yang \& Rose, 2003). Analisis sedimen sering disertakan dalam studi pengkajian lingkungan karena pentingnya sedimen terhadap keseluruhan kualitas sistem perairan. Sedimen merupakan tempat penampungan penting untuk berbagai polutan seperti logam berat dan juga memainkan peran penting dalam daur ulang kontaminan dalam sistem perairan (Maurya \& Malik, 2016). Menurut Yu et al. (2011), logam berat dalam sedimen dapat berada dalam berbagai bentuk dan perikatan, antara lain, sebagai ion bebas dan berikatan dengan karbonat, logam bentuk ini disebut sebagai logam yang sangat labil sehingga mudah lepas ke air serta mudah diserap oleh organisme.

Bahan toksin anorganik, khususnya logam berat menjadi polutan berbahaya karena tidak dapat terdegradasi dan karenanya terakumulasi di lingkungan, sehingga berpotensi untuk mencemari rantai makanan (Paz-Ferreiro et al., 2014), dan cenderung menjadi kontaminan bagi organisme akuatik (Silambarasan et al., 2012; Asante et al., 2014; Riani et al., 2018). 
Logam berat adalah salah satu polutan penting di lingkungan alami karena toksisitas, persistensi, dan masalah bioakumulasinya (Ukoha et al., 2014).

Ikan relatif berada di puncak rantai makanan organisme akuatik, oleh karena itu, ikan biasanya dapat mengakumulasi logam berat dari makanan, air, dan sedimen (Yacoub \& Gad, 2012; Zhao et al., 2012; ElMoselhy et al., 2014; Olusola \& Festus, 2015). Konsentrasi logam berat beracun pada ikan yang dapat mengganggu kesehatan manusia sudah lama diketahui (CastroConzales \& Mendez-Armenta, 2008). Oleh karena itu, dalam evaluasi kesesuaian lahan untuk kegiatan marikultur digunakan persyaratan dari faktor kimia oseanografi yang dipertimbangkan adalah keberadaan logam berat. Toksisitas yang terus-menerus dalam air dan sedimen yang terkena polusi logam berat dapat berdampak serius pada ekosistem perairan. Beberapa organisme akuatik yang mengalami bioakumulasi logam berat, membuatnya tidak aman untuk dikonsumsi. Kontaminasi air oleh logam berat merupakan masalah lingkungan di berbagai tempat. Kegiatan antropogenik terus meningkatkan jumlah logam berat di lingkungan, terutama pada ekosistem perairan (Hasan et al., 2015; Chen et al., 2018). Polusi logam berat dalam sistem perairan tumbuh pada tingkat yang mengkhawatirkan dan telah menjadi masalah penting di seluruh dunia (Olusola \& Festus, 2015), terutama di negara-negara berkembang seperti Indonesia.

Menteri Negara Lingkungan Hidup (MNLH) telah menerbitkan Keputusan Menteri Negara Lingkungan Hidup Nomor 115 tahun 2003 tentang Pedoman Penentuan Status Mutu Air (MNLH, 2003). Agar status mutu air dan sedimen dari logam berat di kawasan pesisir Kabupaten Kepulauan Sangihe diketahui, maka penentuan status mutu air dan sedimen menjadi penting dilakukan. Logam berat menjadi faktor penting dalam status mutu suatu perairan (Mustafa et al., 2019).
Sumberdaya lautan yang mencapai 95\% dari luas total Kabupaten Kepulauan Sangihe (BPS, 2014) merupakan potensi pengembangan yang cukup besar dan dapat memiliki peran penting dan strategis dalam percepatan pembangunan perekonomiannya. Potensi pengembangan yang cukup luas sesungguhnya memiliki keunggulan komparatif, keunggulan kooperatif, dan keunggulan kompetitif untuk menjadi kiprah pembangunan regional dan bahkan nasional di masa datang. Dengan demikian, visi "Kepulauan Sangihe sebagai kabupaten bahari yang sejahtera dan bermartabat" dapat terwujud. Oleh karena itu, informasi awal tentang potensi logam berat sebagai pencemar di kawasan pesisir Kabupaten Kepulauan Sangihe perlu diketahui. Hal penting yang dilakukan adalah menentukan sumber logam berat dan mengelolanya sehingga konsentrasi logam tersebut ketika masuk ke dalam air dan sedimen tidak bersifat beracun. Penelitian ini bertujuan untuk mengetahui konsentrasi beberapa logam berat dalam air dan sedimen serta menentukan status mutunya, terkait dengan potensi pencemaran dan potensi perairan untuk pengembangan marikultur di Kabupaten Kepulauan Sangihe, Provinsi Sulawesi Utara.

\section{METODE PENELITIAN}

\subsection{Lokasi dan Waktu Penelitian}

Penelitian dilaksanakan di kawasan pesisir Pulau Sangihe yaitu di Teluk Talengan (Kecamatan Tabukan Tengah), Teluk Manalu (Kecamatan Tabukan Selatan), dan Teluk Dagho, Teluk Bebu, dan Selat Mahumu (Kecamatan Tamako) serta Teluk Soweang (Kecamatan Manganitu Selatan) yang selanjutnya disebut dengan Teluk Dagho dan sekitarnya. Pengambilan 10 sampel air dan 6 sampel sedimen dilakukan di Teluk Talengan, 6 sampel air dan 4 sampel sedimen di Teluk Manalu, dan 14 sampel air dan 8 sampel sedimen di Teluk Dagho dan sekitarnya. Penelitian dilaksanakan pada 
bulan Agustus dan September 2015. Pengambilan sampel dilakukan secara sesaat dan tidak memperhitungkan waktu atau musim. Pemilihan lokasi kajian didasarkan pada penelitian pendahuluan (Februari 2015) dari hasil desk study, dan juga hasil Diskusi Grup Terfokus yang dilaksanakan di Tahuna, Ibukota Kabupaten Kepulauan Sangihe. Lokasi penelitian merupakan lokasi kegiatan marikultur dan berpotensi sebagai lahan pengembangan marikultur.

\subsection{Pengumpulan Data Lapangan}

Pengambilan sampel air dilakukan dengan menggunakan Kemmerer Water Sampler yang dikompositkan berdasarkan kedalaman yaitu permukaan, tengah, dan dasar perairan. Sampel air diambil sekitar $1 \mathrm{~L}$ pada setiap titik pengambilan sampel. Sampel air disimpan dalam botol polietilen dan diawetkan dengan asam nitrat $\left(\mathrm{HNO}_{3}\right)$ $50 \%$ hingga $\mathrm{pH}$ mencapai 1,5-2,0 dan disimpan dalam kotak yang bersisi es (suhu sekitar $4^{\circ} \mathrm{C}$ ) (APHA-AWWA-WEF, 2012).

Sampel sedimen sekitar $0,5 \mathrm{~kg}$ diambil dengan menggunakan Van Veen Grab yang terbuat dari stainless steel pada setiap titik pengambilan sampel. Sedimen yang diambil adalah sedimen yang tidak bersentuhan langsung dengan Van Veen Grab dan dimasukkan ke dalam wadah yang terbuat dari polietilen yang terlebih dahulu direndam dalam larutan asam $\mathrm{HNO}_{3}$ selama 24 jam kemudian dibilas dengan menggunakan akuades. Pemindahan sampel sedimen dari Van Veen Grab ke dalam wadah polietilen menggunakan sendok plastik. Sampel sedimen dalam wadah polietilen disimpan dalam kotak yang berisi es (suhu sekitar $4^{\circ} \mathrm{C}$ ). Sampel air dan sedimen kemudian dibawa ke laboratorium untuk dianalisis.

\subsection{Persiapan dan Analisis Sampel}

Prosedur analisis logam berat pada sampel air mengikuti petunjuk APHAAWWA-WEF (2012). Sampel air disaring dengan kertas saring Whatman Nomor 41.
Besarnya konsentrasi logam berat dalam air diukur dengan menggunakan Spektrofotometer Serapan Atom atau AAS (Atomic Absorption Spectrophotometry, AAS) varian Spectra AA 50.

Analisis logam berat pada sampel sedimen mengikuti APHA-AWWA-WEF (2012) yaitu dengan metode ekstraksi asam. Sebanyak $0,5 \mathrm{~g}$ sampel yang telah dihaluskan untuk selanjutnya dimasukkan ke dalam labu destruksi kemudian ditambahkan $5 \mathrm{~mL}$ $\mathrm{HNO}_{3}$ (p.a.) dan $0,5 \mathrm{~mL} \mathrm{HClO}_{4}$ (p.a.) lalu dikocok dan dibiarkan semalam. Selanjutnya dipanaskan pada alat destruksi mulai pada suhu $100^{\circ} \mathrm{C}$, setelah uap berwarna kuning habis suhu dinaikkan hingga $200^{\circ} \mathrm{C}$. Destruksi diakhiri sampai keluar uap berwarna putih dan cairan dalam labu destruksi tersisa sekitar $0,5 \mathrm{~mL}$. Setelah cairan dingin, diencerkan dengan $\mathrm{H}_{2} \mathrm{O}$ hingga volume $50 \mathrm{~mL}$, dikocok hingga homogen dan selanjutnya disaring dengan kertas saring Whatman Nomor 41. Besarnya konsentrasi logam berat dalam sedimen diukur dengan menggunakan AAS varian Spectra AA 50.

Logam berat yang dianalisis dalam air dan sedimen adalah $\mathrm{Cu}, \mathrm{Fe}, \mathrm{Hg}, \mathrm{Pb}$, dan $\mathrm{Zn}$ sesuai Biney et al. (1994) untuk potensi pencemar logam dari limbah kegiatan tambang emas. Analisis logam berat dalam air dan sedimen dilakukan di Instalasi Laboratorium Tanah, Balai Pengkajian Teknologi Pertanian Sulawesi Selatan, Maros. Seluruh analisis logam berat diselesaikan sebelum lima minggu setelah pengambilan sampel sesuai petunjuk APHAAWWA-WEF (2012).

\subsection{Analisis Data}

Data yang dianalisis pada penelitian ini diambil bersamaan dengan data lainnya yang telah dilaporkan sebelumnya oleh Mustafa et al. (2017). Status mutu air dan sedimen ditentukan dengan metode Storet (Storage and Retrieval) yang dikembangkan oleh USEPA (2002) dalam Keputusan Menteri Negara Lingkungan Hidup Nomor 115 Tahun 2003 (MNLH, 2003). 
Berdasarkan metode Storet ini dilakukan terlebih dahulu analisis data dengan statistik deskriptif untuk menentukan nilai minimum, maksimum, dan rata-rata dari data setiap logam berat. Hasil analisis data logam berat dalam air dievaluasi dengan membandingkan baku mutu air laut dari Keputusan Menteri Negara Lingkungan Hidup Nomor 51 Tahun 2004 Tentang Baku Mutu Air Laut (KLH, 2004) dan ANZECC (2000) untuk biota laut. Hasil analisis data logam berat dalam sedimen dievaluasi dengan membandingkan baku mutu sedimen laut dari Department of Ecology State of Washington (2013) dan MOECC (1993) untuk biota laut. Penentuan skor mengikuti pendapat Canter (1982) yaitu: didasarkan pada jumlah sampel dan hanya pada peubah kimia. Status mutu air dan sedimen diklasifikasikan dalam empat kelas, yaitu: (1) kelas A: baik sekali, skor $=0$ : memenuhi baku mutu; (2) kelas B: baik, skor $=-1$ sampai dengan -10 : tercemar ringan; (3) kelas C: sedang, skor $=-11$ sampai dengan 30: tercemar sedang; dan (4) kelas D: buruk, skor $\leq-31$ : tercemar berat.

\section{HASIL DAN PEMBAHASAN}

Bahan pencemar yang biasa masuk ke dalam suatu perairan pada prinsipnya dapat dikelompokkan menjadi dua yaitu bahan pencemar yang tidak dapat terurai dan bahan pencemar yang mudah terurai. Sampel bahan pencemar yang tidak dapat terurai berupa persenyawaan logam berat. Masuknya logam berat ke perairan laut dapat mengurangi kualitas atau mutu air dan menimbulkan pencemaran. Selain mengubah mutu air karena logam berat dalam sedimen berpeluang mengalami resuspensi, logam berat yang terendapkan bersama dengan sedimen juga dapat menyebabkan transfer bahan kimia beracun dari sedimen ke organisme akuatik.

\subsection{Logam Berat dalam Air}

Kawasan pesisir sangat produktif dengan keberadaan estuaria, hutan mangrove, padang lamun, dan terumbu karang, sehingga merupakan potensi sumberdaya alam yang besar untuk pembangunan ekonomi. Akan tetapi, laut termasuk kawasan pesisir menjadi tempat pembuangan akhir dari segala kegiatan termasuk yang menghasilkan limbah berupa logam berat. Dari 5 jenis logam berat dalam air dari kawasan pesisir Pulau Sangihe yang dianalisis, didapatkan 4 jenis logam berat yang terdeteksi yaitu: $\mathrm{Cu}$, $\mathrm{Fe}, \mathrm{Pb}$, dan $\mathrm{Zn}$ dan ada 1 jenis logam berat yang hasilnya tidak terdeteksi atau $<0,0001$ $\mathrm{mg} / \mathrm{L}$ yaitu $\mathrm{Hg}$ (Tabel 1).

$\mathrm{Cu}$ termasuk ke dalam kelompok logam esensial, konsentrasi rendah dibutuhkan oleh organisme sebagai koenzim dalam proses metabolisme tubuh, sifat racunnya baru muncul dalam konsentrasi yang tinggi (Cyraniak \& Bolzan, 2014). Rata-rata konsentrasi $\mathrm{Cu} 0,039 ; 0,028$; dan 0,011 mg/L berturut-turut dijumpai di Teluk Talengan, Manalu, dan Dagho dan sekitarnya. Konsentrasi $\mathrm{Cu}$ di ketiga teluk tersebut relatif sama dengan konsentrasi $\mathrm{Cu}$ di Pulau Panjang, Provinsi Banten (Irnawati et al., 2014), tetapi lebih tinggi daripada konsentrasi $\mathrm{Cu}$ di Teluk Jakarta, Daerah Khusus Ibukota Jakarta (Lestari \& Edward, 2004) serta Pulau Muna, Kabaena, dan Buton, Provinsi Sulawesi Tenggara (Ahmad, 2009). Organisme akuatik sangat peka terhadap kelebihan $\mathrm{Cu}$ dalam badan perairan tempat biota tersebut hidup. Konsentrasi $\mathrm{Cu}$ terlarut dalam air laut sebesar $0,01 \mathrm{mg} / \mathrm{L}$ dapat mengakibatkan kematian fitoplankton yang disebabkan daya racun $\mathrm{Cu}$ telah menghambat aktivitas enzim dalam pembelahan sel fitoplankton (Lestari \& Edward, 2004). Jenis organisme akuatik yang termasuk krustasea akan mengalami kematian dalam tenggang waktu 96 jam, apabila konsentrasi $\mathrm{Cu}$ berada dalam kisaran 0,17-100,0 mg/L. Menurut Rompas (2010), melalui jalur nonalamiah, $\mathrm{Cu}$ masuk ke dalam kawasan pesisir sebagai akibat kegiatan antropogenik, misalnya buangan industri, galangan kapal, dan pengolahan industri $\mathrm{Cu}$. 
Tabel 1. Konsentrasi dan Baku Mutu Air Logam Berat di Wilayah Pesisir Pulau Sangihe, Kabupaten Kepulauan Sangihe, Provinsi Sulawesi Utara.

Table 1. Concentration and water quality standards for heavy metals in the coastal area of Sangihe Island, Sangihe Islands Regency, North Sulawesi Province.

\begin{tabular}{|c|c|c|c|c|}
\hline \multirow[b]{2}{*}{ Heavy metals } & \multicolumn{3}{|c|}{ Range (minimum-maximum) and average } & \multirow[b]{2}{*}{$\begin{array}{l}\text { Quality } \\
\text { standard }\end{array}$} \\
\hline & $\begin{array}{l}\text { Talengan Bay } \\
\quad(\mathrm{n}=10)\end{array}$ & $\begin{array}{c}\text { Manalu Bay } \\
(\mathrm{n}=6)\end{array}$ & $\begin{array}{c}\text { Dagho Bay and } \\
\text { surroundings } \\
(\mathrm{n}=14)\end{array}$ & \\
\hline $\mathrm{Cu}(\mathrm{ppm})$ & $0.02-0.05(0.039)$ & $0.01-0.05(0.028)$ & $\begin{array}{c}<0.0001-0.02 \\
(0.011)\end{array}$ & $0.008^{\mathrm{a}}$ \\
\hline $\mathrm{Fe}(\mathrm{ppm})$ & $\begin{array}{l}0.142-0.258 \\
\quad(0.1845)\end{array}$ & $\begin{array}{c}0.180-0.560 \\
(0.3178)\end{array}$ & $\begin{array}{c}0.220-1.138 \\
(0.3633)\end{array}$ & $10^{\mathrm{b}}$ \\
\hline $\mathrm{Hg}(\mathrm{ppm})$ & $<0.0001$ & $<0.0001$ & $<0.0001$ & $0.001^{\mathrm{a}}$ \\
\hline $\mathrm{Pb}(\mathrm{ppm})$ & $\begin{array}{l}0.484-0.832 \\
(0.6242)\end{array}$ & $\begin{array}{c}0.647-0.832 \\
(0.7318)\end{array}$ & $\begin{array}{c}0.400-0.842 \\
(0.6069)\end{array}$ & $0.008^{\mathrm{a}}$ \\
\hline $\mathrm{Zn}(\mathrm{ppm})$ & $\begin{array}{c}<0.0001-0.04 \\
\quad(0.018)\end{array}$ & $0.03-0.04(0.033)$ & $\begin{array}{c}<0.0001-0.22 \\
\quad(0.022)\end{array}$ & $0.050^{\mathrm{a}}$ \\
\hline
\end{tabular}

Information: ${ }^{\mathrm{a}}$ : KLH (2004) for Marine Organisms. ${ }^{\mathrm{b}}$ : ANZECC (2000) for Marine Organisms.

Berdasarkan sudut pandang toksikologi, Fe termasuk logam berat esensial yang keberadaannya dalam jumlah tertentu sangat dibutuhkan oleh organisme, namun dalam jumlah berlebihan dapat menimbulkan efek racun (Cyraniak \& Bolzan, 2014). Pada tanaman lamun, Fe merupakan bagian dari enzim tertentu dan protein yang berfungsi sebagai pembawa elektron pada fase terang fotosintesis dan respirasi dari tanaman (Tahril et al., 2011). Fe dijumpai di ketiga teluk di Pulau Sangihe, tetapi konsentrasi tertinggi dijumpai di Teluk Dagho dan sekitarnya (Tabel 1). Pelabuhan Perikanan Pantai Dagho yang terletak dalam Teluk Dagho menjadi sentra bisnis kelautan dan perikanan terpadu yang dilengkapi dengan areal pelabuhan seluas $32.000 \mathrm{~m}^{2}$ (Mongabay Indonesia, 2016). Hal ini dapat menjadi sumber $\mathrm{Fe}$ sebab keberadaan $\mathrm{Fe}$ dalam air laut dapat bersumber dari perkaratan kapal-kapal laut dan tiang-tiang pancang pelabuhan yang mudah berkarat. Fe dalam air juga diduga disebabkan oleh aktivitas manusia yang terjadi di daratan yaitu buangan limbah rumah tangga yang mengandung $\mathrm{Fe}$ dan korosi pipa-pipa air yang mengandung Fe. Konsentrasi Fe dalam perairan alami berkisar sekitar $0,01 \mathrm{mg} / \mathrm{L}$ (Effendi, 2003).

$\mathrm{Pb}$ merupakan logam berat nonesensial yaitu logam yang keberadaannya dalam tubuh masih belum diketahui manfaatnya, dan bahkan bersifat toksin (Cyraniak \& Bolzan, 2014). Rata-rata konsentrasi $\mathrm{Pb}$ dalam air di Teluk Talengan, Manalu, dan Dagho dan sekitarnya berturutturut 0,$6242 ; 0,7318$; dan $0,6069 \mathrm{mg} / \mathrm{L}$. Nilai yang diperoleh ini lebih tinggi daripada konsentrasi $\mathrm{Pb}$ dalam air di kawasan pesisir lainnya di Indonesia seperti dilaporkan sebelumnya oleh Ahmad (2009) di Pulau Muna, Kabaena, dan Buton; Susantoro et al. (2015) di Selat Berhala, dan Irnawati et al. (2014) di Pulau Panjang. Pb bersifat toksin terhadap biota laut, pada konsentrasi 188 $\mathrm{mg} / \mathrm{L}$ dapat membunuh ikan (Palar, 1994). Pada konsentrasi kronis dapat menyebabkan penghambatan daya tumbuh tubuh dan terjadi pertumbuhan sirip yang aneh pada ikan (Rompas, 2010). Dikatakan pula bahwa polutan $\mathrm{Pb}$ di perairan laut dapat memengaruhi aktivitas biota laut, gangguan yang dapat terjadi akibat polutan ini adalah 
terganggunya susunan syaraf biota, dapat terjadi beberapa ataksia (ataxia) yaitu pergerakan yang tidak terkontrol, keseimbangan renang berkurang, dan apabila menempel di insang dapat menyebabkan kematian. Konsentrasi $\mathrm{Pb}$ yang berlebihan dapat menurunkan kuantitas produksi sebagai akibat pertumbuhan yang lambat dan kematian yang tinggi serta kualitas produksi karena adanya residu logam berat (Rompas, 2010). Sumber pencemaran logam berat khususnya unsur $\mathrm{Pb}$ diduga sebagian berasal dari limbah rumah tangga dan tumpahan bahan bakar minyak perahu atau kapal yang melintasi atau berada di ketiga teluk tersebut di Pulau Sangihe. Telah dilaporkan pula oleh Biney et al. (1994) bahwa bahan bakar minyak dapat berkontribusi terhadap pencemaran $\mathrm{Pb}, \mathrm{Cd}, \mathrm{Ni}, \mathrm{Hg}, \mathrm{Cu}, \mathrm{Fe}$, dan $\mathrm{Mn}$ dalam air. Penyebab lain tingginya konsentrasi $\mathrm{Pb}$ dalan air di kawasan pesisir Pulau Sangihe diduga berasal dari pelapukan alami batuan yang mengandung $\mathrm{Pb}$. Dikatakan oleh Samodra (1994), pemineralan pada batuan gunung api Neogen Akhir atau Plio-Plistosen di Pulau Sangihe menghasilkan $\mathrm{Au}, \mathrm{Fe}, \mathrm{Cu}, \mathrm{Pb}, \mathrm{Zn}$, perak (Ag), serta mineral sulfida (pirit dan kalkopirit).

Seperti halnya dengan $\mathrm{Cu}$ dan $\mathrm{Fe}, \mathrm{Zn}$ termasuk logam berat esensial. Rata-rata konsentrasi $\mathrm{Zn}$ dalam air di Teluk Talengan, Manalu, dan Dagho dan sekitarnya berturutturut 0,018; 0,033; dan 0,022 $\mathrm{mg} / \mathrm{L}$. Konsentrasi $\mathrm{Zn}$ pada perairan alami lebih kecil dari $0,05 \mathrm{mg} / \mathrm{L}$, namun pada perairan yang asam konsentrasinya mencapai $50 \mathrm{mg} / \mathrm{L}$ (Moore, 1991). Konsentrasi $\mathrm{Zn}$ di ketiga teluk juga lebih tinggi daripada konsentrasi Zn di Pulau Muna, Kabaena dan Buton (Ahmad, 2009). Zn bersifat racun dalam konsentrasi tinggi, namun dalam konsentrasi rendah dibutuhkan oleh organisme akuatik sebagai koenzim (Cyraniak \& Bolzan, 2014). Hasil penelitian $\mathrm{LC}_{50}-96$ jam menunjukkan bahwa $\mathrm{Zn}$ pada konsentrasi $60 \mathrm{mg} / \mathrm{L}$ telah dapat mematikan embrio dan larva kerang, Marcenaria marcenaria sebanyak 50\% ( $\mathrm{LC}_{50}-24$ jam) (Calabrese et al., 1977).
Konsentrasi $\mathrm{Zn}$ yang dapat mematikan ikan, udang, dan kerang dari laut berturut-turut 60; 0,5-50; dan 10-50 mg/L pada pemaparan 96 jam (Palar, 1994). Apabila konsentrasi Zn melimpah di perairan laut akan mengancam keselamatan manusia. Walaupun konsentrasi Zn dalam air di Pulau Sangihe relatif lebih tinggi daripada perairan lainnya di Indonesia, tetapi masih lebih rendah daripada baku mutu yang telah ditetapkan oleh KLH (2004). Sumber pencemaran $\mathrm{Zn}$ adalah adanya aktivitas pembuangan limbah rumah tangga, limbah pertanian yang banyak menggunakan pupuk dan pestisida, peningkatan aktivitas industri, serta adanya aktivitas pembuangan limbah domestik lain yang mengandung $\mathrm{Zn}$.

$\mathrm{Hg}$ merupakan logam berat yang menduduki urutan pertama dalam hal sifat racunnya, dibandingkan dengan logam berat lainnya terhadap organisme akuatik. $\mathrm{Hg}$ dalam air di kawasan pesisir Pulau Sangihe tidak terdeteksi atau $<0,0001 \mathrm{mg} / \mathrm{L}$ seperti disebutkan sebelumnya. Keberadaan tambang emas yang dalam prosesnya menggunakan $\mathrm{Hg}$ belum memberikan dampak negatif terhadap kawasan pesisir di Pulau Sangihe, tetapi kegiatan tambang emas tetap harus mendapat perhatian ke depannya. Telah ditetapkan melalui "Tujuh Instruksi Presiden terkait Penggunaan Merkuri pada Pertambangan Rakyat" agar melakukan pengaturan kembali tata kelola pertambangan rakyat dan pertambangan emas skala kecil yang berada di luar maupun di dalam kawasan hutan serta menginstruksikan agar penggunaan $\mathrm{Hg}$ pada tambang-tambang rakyat harus segera dihentikan (Kemensekneg, 2017). Beberapa daerah di Provinsi Sulawesi Utara yang terdapat kegiatan tambang emasnya, seperti di perairan Ratatotok dijumpai konsentrasi $\mathrm{Hg}$ sebesar 0,7-1,2 $\mathrm{mg} / \mathrm{L}$, di perairan Lanut didapatkan konsentrasi sebesar 0,5-3,0 mg/L, dan di perairan Manado ditemukan konsentrasi sebesar 0,8-2,0 mg/L (Rompas, 2010).

Hasil analisis penentuan status mutu air diperoleh nilai skor total -40 di Teluk 
Talengan dan Manalu dan skor total -36 di Teluk Dagho dan sekitarnya (Tabel 2). Skor total yang dipeoleh ini menunjukkan bahwa ketiga teluk termasuk kelas D (buruk) atau termasuk tercemar berat yang sumbernya berasal dari logam berat $\mathrm{Pb}$ dan $\mathrm{Cu}$.

\subsection{Logam Berat dalam Sedimen}

Konsentrasi logam berat dalam sedimen di Teluk Talengan, Manalu, dan Dagho dan sekitarnya sangat bervariasi (Tabel 3). Apabila konsentrasi logam berat dalam sedimen ini dibandingkan dengan logam berat dalam air, maka konsentrasi logam berat dalam sedimen jauh lebih tinggi daripada logam berat dalam air. Lebih tingginya konsentrasi logam dalam sedimen sebagai akibat terjadinya akumulasi dalam sedimen dalam waktu yang cukup lama. Beberapa material yang terkonsentrasi di udara dan permukaan air mengalami oksidasi, radiasi ultraviolet, evaporasi dan polimerisasi, jika tidak mengalami proses pelarutan, material ini akan saling berikatan dan bertambah berat sehingga tenggelam dan menyatu dalam sedimen (Okuo \& Okolo, 2011). Logam berat dalam air yang diserap oleh partikel tersuspensi akan menuju dasar perairan, menyebabkan konsentrasi logam dalam sedimen menjadi lebih tinggi dan sebaliknya dalam air menjadi lebih rendah (Viet et al., 2016). Selain itu, konsentrasi logam berat dalam air cenderung tidak terjadi akumulasi sebagai akibat terjadinya pengenceran dari pembilasan air laut pada setiap pasang dan surut.

Sedimen berperan penting dalam menentukan kualitas air dikarenakan peranannya sebagai tujuan akhir dari limbah. Selain itu sedimen mempunyai potensi pelepasan zat-zat tercemar ke dalam badan perairan disertai perubahan kondisi fisik dan kimiawi (Zainal \& Diani, 2009). Sedimen yang terkontaminasi dapat menyebabkan penurunan keanekaragaman hayati ekosistem dan memengaruhi sistem perairan dan rantai makanan (Maurya \& Malik, 2016). Adanya akumulasi logam berat dalam sedimen dan menjadikan adanya akumulasi pada tubuh biota yang hidup dan mencari makan di dalam air maupun di sekitar sedimen, dan akan mencemari habitat biota laut, yang pada gilirannya akan berbahaya bagi manusia yang mengonsumsinya.

Berdasarkan dari 5 logam berat yang dianalisis dalam sedimen di Teluk Talengan, Manalu, dan Dagho dan sekitarnya, ada 4 logam berat yang terdeteksi yaitu, $\mathrm{Pb}, \mathrm{Zn}, \mathrm{Fe}$, dan $\mathrm{Cu}$, sedangkan logam berat yang tidak terdeteksi atau $<0,0001 \mathrm{ppm}$ adalah $\mathrm{Hg}$. Jenis logam berat yang terdeteksi maupun yang tidak terdeteksi dalam sedimen ini sama dengan yang dijumpai dalam air seperti telah dijelaskan sebelumnya.

Tabel 2. Skor Status Kualitas Air (Storet) Berdasarkan Konsentrasi Logam Berat di Wilayah Pesisir Pulau Sangihe, Kabupaten Kepulauan Sangihe, Provinsi Sulawesi Utara.

Table 2. Water quality status score (Storet) based on the concentration of heavy metals in the coastal area of Sangihe Island, Sangihe Islands Regency, North Sulawesi Province.

\begin{tabular}{lccc}
\hline \multirow{2}{*}{ Heavy metals } & \multicolumn{3}{c}{ Score } \\
\cline { 2 - 4 } & Talengan Bay & Manalu Bay & Dagho Bay and surroundings \\
\hline $\mathrm{Cu}$ & -20 & -20 & -16 \\
$\mathrm{Fe}$ & 0 & 0 & 0 \\
$\mathrm{Hg}$ & 0 & 0 & 0 \\
$\mathrm{~Pb}$ & -20 & -20 & -20 \\
$\mathrm{Zn}$ & 0 & 0 & 0 \\
Total score & -40 & -40 & -36 \\
\hline \multirow{2}{*}{ Criteria } & Class D: poor, & Class D: poor, & Class D: poor, \\
& heavily polluted & heavily polluted & heavily polluted \\
\hline
\end{tabular}


Tabel 3. Standar konsentrasi dan kualitas sedimen logam berat di wilayah pesisir Pulau Sangihe, Kabupaten Kepulauan Sangihe, Provinsi Sulawesi Utara.

Table 3. Concentration and sediment quality standards for heavy metals in the coastal area of Sangihe Island, Sangihe Islands Regency, North Sulawesi Province.

\begin{tabular}{|c|c|c|c|c|}
\hline \multirow[b]{2}{*}{ Heavy metals } & \multicolumn{3}{|c|}{ Range (minimum-maximum) and average } & \multirow[b]{2}{*}{$\begin{array}{c}\text { Quality } \\
\text { standard }\end{array}$} \\
\hline & Talengan Bay $(\mathrm{n}=6)$ & $\begin{array}{l}\text { Manalu Bay } \\
(\mathrm{n}=4)\end{array}$ & $\begin{array}{c}\text { Dagho Bay and } \\
\text { surroundings }(\mathrm{n}=8)\end{array}$ & \\
\hline $\mathrm{Cu}(\mathrm{mg} / \mathrm{L})$ & $\begin{array}{c}94.88-134.39 \\
(109.438)\end{array}$ & $\begin{array}{c}77.09-102.85 \\
(89.235)\end{array}$ & $\begin{array}{c}131.09-161.39 \\
(138.858)\end{array}$ & $390^{\mathrm{a}}$ \\
\hline $\mathrm{Fe}(\mathrm{mg} / \mathrm{L})$ & $\begin{array}{l}465.0-3,643.0 \\
(2,162.00)\end{array}$ & $\begin{array}{c}452.0-3,282.0 \\
(1,855.75)\end{array}$ & $\begin{array}{c}1,2650.0-3,758.0 \\
(2,417.88)\end{array}$ & $20.000^{b}$ \\
\hline $\mathrm{Hg}(\mathrm{mg} / \mathrm{L})$ & $<0.0001$ & $<0.0001$ & $<0.0001$ & $0.41^{\mathrm{a}}$ \\
\hline $\mathrm{Pb}(\mathrm{mg} / \mathrm{L})$ & $\begin{array}{c}45.42-86.97 \\
(67.938)\end{array}$ & $\begin{array}{l}12.99-91.50 \\
(50.593)\end{array}$ & $\begin{array}{c}50.00-73.41 \\
(65.890)\end{array}$ & $450^{\mathrm{a}}$ \\
\hline $\mathrm{Zn}(\mathrm{mg} / \mathrm{L})$ & $\begin{array}{c}2.81-33.71 \\
(18.598)\end{array}$ & $\begin{array}{c}4.20-26.84 \\
(15.438)\end{array}$ & $\begin{array}{c}17.39-60.89 \\
(33.180)\end{array}$ & $410^{\mathrm{a}}$ \\
\hline
\end{tabular}

Information: ${ }^{\mathrm{a}}$ : Department of Ecology State of Washington (2013) for Marine Organisms. ${ }^{\mathrm{b}}$ : MOECC (2011) for Marine Organisms.

Yilmaz et al. (2010) menyatakan bahwa $\mathrm{Cu}$ merupakan indikator yang baik dengan adanya pencemaran dari aktivitas antropogenik. Rata-rata konsentrasi $\mathrm{Cu}$ dalam sedimen di Teluk Talengan, Manalu, dan Dagho dan sekitarnya berturut-turut 109,438; 89,235; dan 138,858 ppm. Konsentrasi ini lebih tinggi daripada yang telah dilaporkan sebelumnya oleh Ahmad (2009), Irnawati et al. (2014), dan Susantoro et al. (2015) di beberapa kawasan pesisir Indonesia. Konsentrasi $\mathrm{Cu}$ dalam sedimen masih tergolong memenuhi baku mutu untuk biota laut. Fe dalam sedimen di Teluk Talengan, Manalu, dan Dagho dan sekitarnya dijumpai dengan rata-rata berturut-turut $2.164,00 ; 1.855,75$; dan 2.417,88 ppm. Seperti halnya dengan konsentrasi Fe dalam air, konsentrasi Fe dalam sedimen didapatkan tertinggi di Teluk Dagho dan sekitarnya. Di Teluk Dagho dijumpai Pelabuhan Perikanan Pantai Dagho yang dapat menjadi sumber Fe sebab keberadaan Fe dalam air laut dapat bersumber dari perkaratan kapal-kapal laut dan tiang-tiang pancang pelabuhan yang mudah berkarat. Namun demikian, konsentrasi $\mathrm{Fe}$ dalam sedimen masih memenuhi baku mutu untuk biota laut.
Rata-rata konsentrasi $\mathrm{Pb}$ dalam sedimen di Teluk Talengan, Manalu, dan Dagho dan sekitarnya berturut-turut adalah 67,938; 50,593; dan 65,890 ppm. Konsentrasi $\mathrm{Pb}$ ini lebih tinggi daripada konsentrasi $\mathrm{Pb}$ dalam sedimen Selat Berhala (Susantoro et al., 2015); Pulau Panjang (Irnawati et al., 2014); dan Pulau Muna, Kabaena, dan Buton (Ahmad, 2009). Namun demikian, konsentrasi $\mathrm{Pb}$ dalam sedimen ini masih berada dalam baku mutu biota laut. Rata-rata konsentrasi $\mathrm{Zn}$ dalam sedimen di Teluk Talengan, Manalu, dan Dagho dan sekitarnya berturut-turut 18,$598 ; 15,438$; dan 33,180 ppm. Dari ketiga teluk di Pulau Sangihe, konsentrasi tertinggi $\mathrm{Zn}$ dijumpai di Teluk Dagho dan sekitarnya. Seperti halnya dengan $\mathrm{Cu}, \mathrm{Zn}$ secara umum merupakan indikator yang baik terhadap pencemaran antropogenik (Yilmaz et al., 2010), sehingga kemungkinan $\mathrm{Zn}$ di air dan sedimen pada ketiga teluk berasal dari sumber pencemaran yang tidak muncul secara alami, tetapi ada pengaruh dari aktivitas manusia. Telah dilaporkan sebelumnya bahwa di Teluk Dagho terdapat Pelabuhan Perikanan Pantai.

Dagho yang berkonsekuensi terhadap munculnya berbagai kegiatan yang lebih 
Tabel 4. Skor Status Kualitas Sedimen (Storet) Berdasarkan Konsentrasi Logam Berat di Wilayah Pesisir Pulau Sangihe, Kabupaten Kepulauan Sangihe, Provinsi Sulawesi Utara.

Table 4. Sediment quality status score (Storet) based on the concentration of heavy metals in the coastal area of Sangihe Island, Sangihe Islands Regency, North Sulawesi Province.

\begin{tabular}{lccc}
\hline \multirow{2}{*}{ Heavy metals } & \multicolumn{3}{c}{ Score } \\
\cline { 2 - 4 } & Talengan Bay & Manalu Bay & Dagho Bay and surroundings \\
\hline $\mathrm{Cu}$ & 0 & 0 & 0 \\
$\mathrm{Fe}$ & 0 & 0 & 0 \\
$\mathrm{Hg}$ & 0 & 0 & 0 \\
$\mathrm{~Pb}$ & 0 & 0 & 0 \\
$\mathrm{Zn}$ & 0 & 0 & 0 \\
Total score & 0 & 0 & 0 \\
\hline \multirow{2}{*}{ Criteria } & Class A: excellent, & Class A: excellent, & Class A: excellent, \\
& fulfilling standard & fulfilling standard & fulfilling standard \\
& quality & quality & quality \\
\hline
\end{tabular}

banyak yang dapat menyebabkan pencemaran $\mathrm{Zn}$ berupa pencemaran antropogenik. Konsentrasi $\mathrm{Zn}$ ini relatif sama dengan konsentrasi $\mathrm{Zn}$ dalam sedimen Selat Berhala (Susantoro et al., 2015) dan Pulau Muna, Kabaena, dan Buton (Ahmad, 2009). Seperti halnya dengan $\mathrm{Cu}, \mathrm{Pb}, \mathrm{Fe}$, dan $\mathrm{Hg}$, konsentrasi $\mathrm{Zn}$ ini tergolong memenuhi baku mutu untuk biota laut. Dalam hal ini, semua logam yang dianalisis dalam sedimen di kawasan pesisir Pulau Sangihe termasuk memenuhi baku mutu untuk biota laut.

Hasil analisis penentuan status mutu sedimen diperoleh nilai skor total sebesar 0 di ketiga teluk di Pulau Sangihe (Tabel 4). Skor total yang diperoleh ini menunjukkan bahwa ketiga teluk termasuk kelas A (baik sekali) atau memenuhi baku mutu. Hal ini menunjukkan bahwa sedimen di kawasan pesisir Pulau Sangihe tergolong belum tercemar, tidak seperti dengan logam berat $\mathrm{Cu}$ dan $\mathrm{Pb}$ dalam air yang sudah tergolong kelas D (buruk) atau tercemar berat.

\subsection{Perspektif terhadap Pengembangan Marikultur}

Berbagai komoditas untuk marikultur seperti: ikan, udang, teripang, kerang, dan rumput laut membutuhkan persyaratan kondisi perairan tertentu untuk tumbuh, hidup, dan bereproduksi dengan baik. Satu di antara persyaratan kondisi perairan itu adalah adanya cemaran termasuk logam berat. Walaupun semua logam berat dalam sedimen yang dianalisis dari kawasan pesisir Pulau Sangihe tergolong memenuhi baku mutu, tetapi adanya logam berat $\mathrm{Cu}$ dan $\mathrm{Pb}$ dalam air yang tergolong tercemar berat dapat menjadi potensi pencemar logam berat dalam sedimen, apabila pencemaran terjadi terus menerus dan terakumulasi dalam sedimen. Logam berat yang terlarut dalam air akan berpindah ke dalam sedimen apabila berikatan dengan material organik bebas atau material organik yang melapisi permukaan sedimen dan penyerapan langsung oleh permukaan partikel sedimen. Apabila hal ini tidak dilakukan pencegahan dini terhadap kontaminasi logam berat, maka akan berdampak pada kehidupan biota laut terlebih lagi manusia yang mengonsumsinya. Oleh karena itu diperlukan upaya untuk mengurangi kegiatan-kegiatan yang dapat menjadi sumber pencemar logam berat, terutama $\mathrm{Cu}$ dan $\mathrm{Pb}$ dengan harapan kegiatanperikanan termasuk marikultur dapat meningkat produksinya, baik kuantitas 
maupun kualitas dan berkelanjutan di Pulau Sangihe.

Upaya yang dapat dilakukan dalam rangka mengurangi sumber pencemar dari logam berat adalah dengan memberantas PETI di Kabupaten Kepulauan Sangihe. Pemerintah Kabupaten Kepulauan Sangihe dan Pemerintah Provinsi Sulawesi Utara (2016) secara tegas telah menolak keberadaan tambang emas di Kabupaten Kepulaun Sangihe karena merusak lingkungan. Upaya lain yang dapat dilakukan yaitu dengan pengelolaan secara berkelanjutan untuk meminimalisir terjadinya pencemaran logam berat di kawasan pesisir adalah pemantauan, pembinaan, dan penegakan hukum. Pemantauan dapat dilakukan secara berkala melalui analisis kualitas lingkungan sekitar lokasi PETI untuk kualitas air termasuk logam berat, logam berat dalam sedimen, serta $\mathrm{Hg}$ dalam biota dan rambut pengolah PETI. Pembinaan dilakukan terhadap pengolah PETI melalui pelatihan tentang pengelolaan dan pemanfaatan tambang emas secara benar dan aman. Dalam rangka penegakan hukum, secara umum prosedur penanganannya sama dengan perkara tindak pidana umum lainnya. Adapun tindakan-tindakan yang dapat dilakukan oleh Polisi Resort (Polres) Kabupaten Kepulauan Sangihe dalam memberantas tindak pidana PETI yaitu berupa: tindakan preventif (pencegahan) dan tindakan penindakan. Tindakan preventif yang dapat dilakukan oleh Polres Kabupaten Kepulauan Sangihe berupa: (1) himbauan baik secara tertulis maupun tidak tertulis kepada masyarakat agar tidak melakukan penambangan emas ilegal, (2) bersama Pemda Kabupaten Kepulauan Sangihe melakukan sosialisasi tentang dampak penambangan emas ilegal terhadap masyarakat, keanekaragaman hayati, dan lingkungan hidup, (3) melakukan sosialisasi mengenai sanksi terhadap kegiatan penambangan emas ilegal, dan (4) pendekatan dengan tokoh-tokoh masyarakat, pemuda, dan adat. Tindakan penindakan yang dapat dilakukan oleh Polres Kabupaten Kepulauan Sangihe meliputi: (1) melakukan penyelidikan, (2) melakukan penyidikan, (3) kalau sudah cukup unsur pihak kepolisian melakukan penangkapan kepada tersangka, tetapi lebih sering melakukan tangkap tangan (4) melakukan penahanan, penggeledahan, dan (6) penyitaan.

\section{KESIMPULAN}

Hasil analisis dari 5 logam berat didapatkan 4 logam berat yang terdeteksi yaitu $\mathrm{Cu}, \mathrm{Fe}, \mathrm{Pb}$, dan $\mathrm{Zn}$ dalam air dan sedimen, sedangkan 1 logam berat yang tidak terdeteksi yaitu $\mathrm{Hg}$ di kawasan pesisir Pulau Sangihe, Kabupaten Kepulauan Sangihe, Provinsi Sulawesi Utara. Hasil penentuan status mutu air dan sedimen menunjukkan bahwa air kawasan pesisir Pulau Sangihe tergolong tercemar berat berdasarkan konsentrasi logam berat $\mathrm{Cu}$ dan $\mathrm{Pb}$, sedangkan sedimennya tergolong memenuhi baku mutu berdasarkan konsentrasi logam berat untuk biota laut.

\section{UCAPAN TERIMA KASIH}

Diucapkan terima kasih kepada Bapak Hakim Madeng, Muhammad Arnol, dan Ilham atas bantuannya dalam pengambilan sampel air dan sedimen di lapangan. Terima kasih juga disampaikan kepada Kepala dan staf Dinas Kelautan dan Perikanan Kabupaten Kepulauan Sangihe atas bantuannya selama pelaksanaan penelitian ini. Penelitian ini dibiayai dari Daftar Isian Pelaksanaan Anggaran yang ada di Pusat Penelitian dan Pengembangan Perikanan Budidaya Tahun Anggaran 2015.

\section{DAFTAR PUSTAKA}

Ahmad, F. 2009. Tingkat pencemaran logam berat dalam air laut dan sedimen di perairan Pulau Muna, Kabaena, dan Buton Sulawesi Tenggara. Makara, Sains, 13(2): 117-124. 
https://doi.org/10.7454/mss.v13i2.407

American Public Health Association (APHA)-American Water Works Association (AWWA)-Water Environment Federation (WEF). 2012. Standard methods for the examination of water and wastewater. $22^{\text {nd }}$ Edition. American Public Health AssociationAmerican Water Works AssociationWater Environment Federation. Washington, D.C. 1360 p.

Anbuselvan, N., D.S. Nathan, \& M. Sridharan. 2018. Heavy metal assessment in surface of Coromandel Coast of India: Implication in marine pollution. Marine Pollution Bulletin, 131(Part A): 712-726.

https://doi.org/10.1016/j.marpolbul.201 8.04.074

Australian and New Zealand Environment and Conservation Council (ANZECC). 2000. National water quality management strategy. Australian and New Zealand Environment and Conservation Council. Canberra. 79 p. https://www.waterquality.gov.au/sites/ default/files/documents/anzeccarmcanz-2000-guidelines-voll.pdf

Asante, F., E. Agbeko, G. Addae, \& A.K. Quainoo. 2014. Bioaccumulation of heavy metals in water, sediments and tissues of some selected fishes from the Red Volta, Nangodi in the upper east region of Ghana. British J. of Applied Science and Technology, 4(4): 594603.

https://doi.org/10.9734/BJAST/2014/5 389

Biney, C., A.T. Amuzu, D. Calamari, N. Kaba, L.L. Mbome, H. Naeve, P.B.O. Ochumba, O. Osibanjo, V. Radegonde, \& M.A.H. Saad. 1994. Review of heavy metals in the African aquatic environment. Ecotoxicology and Environmental Safety, 28(2): 134-159. https://doi.org/10.1006/eesa.1994.1041

Badan Pusat Statistik (BPS). 2014. Kepulauan Sangihe dalam angka 2014.
Badan Pusat Statistik Kabupaten Kepulauan Sangihe, Tahuna. $388 \mathrm{hlm}$. https://sangihekab.bps.go.id/

Calabrese, A., J.R. MacInnes, D.A. Nelson, \& J.E. Miller. 1977. Survival and growth of bivalve larvae under heavy metals stress. Marine Biology, 41: 179184.

https://doi.org/10.1007/BF00394024

Canter, L.W. 1982. Environmental impact assessment. Impact Assessment, 1(2): 6-40.

https://doi.org/10.1080/07349165.1982 .9725447

Castro-Conzales, M.I. \& M. MendezArmenta. 2008. Heavy metals implications associated to fish consumption. Environmental Toxicology and Pharmacology, 26: 263-271.

https://doi.org/10.1016/j.etap.2008.06.0 01

Chen, F., J. Lin, B. Qian, Z. Wu, P. Huang, K. Chen, T. Li, \& M. Cai. 2018. Geochemical assessment and spatial analysis of heavy metals in the surface sediments in the eastern Beibu Gulf: A reflection on the industrial development of South China Coast. International $J$. of Environmental Research and Public Health, 15: 496507.

https://doi.org/10.3390/ijerph15030496

Cyraniak, E. \& B.D. Bolzan. 2014. Heavy metals in circulation biogeochemical. World Scientific News, 6: 30-36. https://www.infona.pl/resource/bwmeta 1.element.psjd-6f87e9e6-dbdf-47749d29-1cd44fa58093

Department of Ecology State of Washington. 2013. Sediment management standardChapter 173-204 WAC. Revised February 2013, Effective September 2013, Publication no. 13-09-055. Washington State Department of Ecology. Olympia. 135 p. https://fortress.wa.gov/ecy/publications /SummaryPages/1309055.html 
Effendi, H. 2003. Telaah kualitas air: Bagi pengelolaan sumberdaya dan lingkungan perairan. Penerbit Kanisius. Jakarta. $258 \mathrm{hlm}$.

El-Moselhy, Kh., A.I. Othman, H.A. ElAzem, \& M.E.A. El-Metwally. 2014. Bioaccumulation of heavy metals in some tissues of fish in the Red Sea, Egypt. Egyption J. of Basic and Applied Science, 1(2): 97-105. https://doi.org/10.1016/j.ejbas.2014.06. 001

Förstner, U. \& G.T.W. Wittmann. 1981. Metal pollution in the aquatic environment. Springer-Verlag, Berlin, Heidelberg, New York. 486 p.

https://doi.org/10.1007/978-3-64269385-4

Hasan, S.J., M.B. Tanu, Md.H. Haidar, T. Ahmed, \& A.K.M.S.A. Rubel. 2015. Physico-chemical characteristics and accumulation of heavy metals in water and sediments of the river Dakatia, Bangladesh. International J. of Fisheries and Aquatic Studies, 2(5): 300-304.

https://www.fisheriesjournal.com/archi ves/2015/vol2issue5/PartE/2-5-86993.pdf

Heyvart, A.C., J.E. Reuter, D.G. Sloton, \& C.R. Goldman. 2000. Paleolimnological reconstruction of historical atmospheric lead and mercury deposition at Lake Tahoe, California-Nevada. Environmental Science and Technology, 34: 35883597.

https://doi.org/10.1021/es991309p

Irnawati, R., A. Susanto, Mustahal, \& M.A. Syabana. 2014. Heavy metals concentration in water and sediment at Panjang Island, Serang Regency, Banten Province, Indonesia. AES Bioflux, 6(3): 256-260.

https://www.aes.bioflux.com.ro/docs/2 014.256-260.pdf

Kementerian Sekretariat Negara (Kemensekneg). 2017. Tujuh instruksi presiden terkait penggunaan merkuri pada pertambangan rakyat. Kementerian Sekretariat Negara Republik Indonesia. Jakarta. $1 \mathrm{hlm}$. https://ksp.go.id/tujuh-instruksipresiden-terkait-penggunaan-merkuripada-pertambangan-rakyat/

Kementerian Lingkungan Hidup (KLH). 2004. Keputusan Menteri Negara Kependudukan dan Lingkungan Hidup nomor 51 tahun 2004, tanggal 8 April 2004 tentang baku mutu air laut. Kementerian Lingkungan Hidup. Jakarta. 10 hlm.

Lestari \& Edward. 2004. Dampak pencemaran logam berat terhadap kualitas air laut dan sumberdaya perikanan (Studi kasus kematian massal ikan-ikan di Teluk Jakarta). Makara, Sains, 8(2): 52-58. https://doi.org/10.7454/mss.v8i2.414

Makagansa, N.J. 2013. Delapan pertambangan di Sangihe tidak memiliki izin. Fokus Manado. www.fokusmanado.com/2013/04/8pertambangan-di-sangihe-tidak.html. Diakses 12 Februari 2017.

Maurya, P.K. \& D.S. Malik. 2016. Distribution of heavy metals in water, sediments and fish tissue (Heteropneustis fossilis) in Kali River of western U.P. India. International $J$. of Fisheries and Aquatic Studies, 4(2): 208-215.

https://www.researchgate.net/publicatio $\mathrm{n} / 299846379$

Menteri Negara Lingkungan Hidup (MNLH). 2003. Keputusan Menteri Negara Lingkungan Hidup nomor: 115 tahun 2003 tentang pedoman penentuan status mutu air. Menteri Negara Lingkungan Hidup. Jakarta. 15 hlm. https://luk.staff.ugm.ac.id/atur/sda/Kep menLH115-2003StatusMutuAir.pdf

Ministry of Environment and Energy of Canada (MOECC). 1993. Guidelines for the protection and management of aquatic sediment quality in Ontario. 
Ministry of Environment and Energy. Ontario. 27 p.

https://www.ontario.ca/document/guide lines-identifying-assessing-andmanaging-contaminated-sedimentsontario

Mongabay Indonesia. 2016. Liputan Sangihe: Tepatkah Dagho jadi sentra perikanan? (Bagian kedua). Mongabay Indonesia, Situs Berita Lingkungan, 30 September 2016.

https://www.mongabay.co.id/2016/09/3 0/liputan-sangihe-tepatkan-dagho-jadisentra-perikanan-bagian-2/

Moore, J.W. 1991. Inorganic contaminants of surface water. Springer-Verlag. New York. 334 p.

https://doi.org/10.1007/978-1-46123004-5

Mustafa, A., Hasnawi, Tarunamulia, M.B. Selamat, \& M.F. Samawi. 2019. Distribusi polutan logam berat di perairan pantai yang digunakan untuk memasok tambak udang terdekat dan mitigasinya di Kecamatan Jabon Provinsi Jawa Timur. J. Riset Akuakultur, 14(2): 127-138.

https://doi.org/10.15578/jra.14.2.2019. 127-138

Mustafa, A., Tarunamulia, Hasnawi, \& I.N. Radiarta. 2017. Karakteristik dan kesesuaian perairan untuk budidaya rumput laut di Kabupaten Kepulauan Sangihe, Sulawesi Utara. J. Riset Akuakultur, 12(2): 187-196.

https://doi.org/10.15578/jra.12.2.2017. 187-196

Okuo, J.M. \& P.O. Okolo. 2011. Levels of $\mathrm{As}, \mathrm{Pb}, \mathrm{Cd}$, and $\mathrm{Fe}$ in suspended particulate matter (SPM) in ambient air of Artisan Workshops in Benin City, Nigeria. Bayero J. of Pure and Applied Sciences, 4(2): 97-99. https://doi.org/10.4314/bajopas.v4i2.19

Olusola, J.O. \& A.A. Festus. 2015. Assessment of heavy metals in some marine fish species relevant to their concentration in water and sediment from coastal waters of Ondo State, Nigeria. $J$. of Marine Science: Research \& Development, 5(2): 1-6. https://doi.org/10.4172/21559910.1000163

Palar, H. 1994. Pencemaran dan toksokologi logam berat. Rineka Cipta. Jakarta. 90 hlm. https://opac.perpusnas.go.id/DetailOpa c. aspx $? \mathrm{id}=588643$

Paz-Ferreiro, J., H. Lu, S. Fu, A. Mendez, \& G. Gasco. 2014. Use of phytoremediation and biochar to remediate heavy metal polluted soils: A review. Solid Earth, 5: 65-75.

https://doi.org/10.5194/se-5-65-2014

Pemerintah Kabupaten Kepulauan Sangihe dan Pemerintah Provinsi Sulawesi Utara. 2016. Empat kampung jadi lokasi eksplorasi. Manado Post Online. Diakses 17 Juni 2018. http://manadopost.id/read/2016/07/23/ Empat-Kampung-Jadi-LokasiEksplorasi/15586

Riani, E., M.R. Cordova, \& Z. Arifin. 2018. Heavy metal pollution and its relation to the malformation of green mussels cultured in Muara Kamal waters, Jakarta Bay, Indonesia. Marine Pollution Bulletin, 133: 664-670.

https://doi.org/10.1016/j.marpolbul.201 8.06.029

Rompas, R.M. 2010. Toksikologi kelautan. PT Walaw Bengkulen. Jakarta. 275 hlm.

Samad, M.A., Y. Mahmud, R.K. Adhikary, S.B.M. Rahman, M.S. Haq, \& H. Rashid. 2015. Chemical profile and heavy metal concentration in water and freshwater species of Rupsha River, Bangladesh. American J. of Environmental Protection, 3(6): 180186. https://doi.org/10.12691/env-3-6-1 Samodra, H. 1994. Peta geologi lembar Sangihe dan Siau, Sulawesi. Pusat Penelitian dan Pengembangan Geologi. Bandung. $1 \mathrm{hlm}$. 
https://opac.perpusnas.go.id/DetailOpa c. $\operatorname{aspx}$ ?id=711142

Silambarasan, K., P. Senthilkumaar, \& K. Velmurugan. 2012. Studies on the distribution of heavy metal concentrations in River Adyar, Chennai, Tamil Nadu. European J. of Experimental Biology, 2(6): 21922198.

https://www.researchgate.net/publicatio $\mathrm{n} / 273135794$

Susantoro, T.M., D. Sunarjanto, \& A. Andayani. 2015. Distribusi logam berat pada sedimen di perairan muara dan laut Propinsi Jambi. J. Nasional Kelautan, 10(1): 1-12. https://doi.org/10.15578/jkn.v10i1.4

Tahril, P. Taba, L.N. Nafie, \& A. Noor. 2011. Analisis besi dalam ekosistem lamun dan hubungannya dengan sifat fisikokimia perairan pantai Kabupaten Donggala. J. Natur Indonesia, 13(2): 105-111.

https://repository.unhas.ac.id/handle/12 3456789/2622

Tamon, F.B. 2013. Pusat emas di Sangihe ada di Desa Ojumahe dan Pintareng. Berita Manado.

https://beritamanado.com/emas-disangihe/. Diakses 12 Februari 2017.

Ukoha, P.O., N.R. Ekere, U.V. Udeogu, \& V.E. Agbazue. 2014. Potential health risk assessment of heavy metals $(\mathrm{Cd}$, $\mathrm{Cu}$ and $\mathrm{Fe}$ ) concentrations in some imported frozen fish species consumed in Nigeria. International $J$. of Chemical Sciences, 12: 366-374. https://www.researchgate.net/publicati on/267777719

Viet, T.T., N.D. Khanh, N.P. Bao, N.N. Sang, D.Q. Tuc, N.P. Dan, E. Strady, \& S. Han. 2016. Distribution of heavy metals in surface water, suspended particulate matter, sediment and clam (Meretrix lyrata) from downstream of Saigon-Dong Nai River, Vietnam. J. of Science and Technology, 54(2A): 207213. https://horizon.documentation.ird.fr/exl -doc/pleins_textes/divers17-

07/010070477.pdf

Yacoub, A.M. \& N.S. Gad. 2012. Accumulation of some heavy metals and biochemical alterations in muscles of Oreochromis niloticus from the River Nile in Upper Egypt. International $J$. of Environmental Science and Engineering, 3: 1-10.

https://www.pvamu.edu/engineering/w p-content/uploads/sites/30/IJESE-vol3-Issue-1-online.pdf

Yang, H. \& N.L. Rose. 2003. Distribution of $\mathrm{Hg}$ in the lake sediments across the U. K. Science of the Total Environment, 304: 391-404. https://doi.org/10.1016/S00489697(02)00584-3

Yilmaz, A.B., C. Turan, \& T. Toker. 2010. Uptake and distribution of hexavalent chromium in tissues (gill, skin and muscle) of a freshwater fish, tilapia, Oreochromis aureus. J. of Environmental Chemistry and Ecotoxicology, 2(3): 28-33. https://doi.org/10.5897/JECE.9000062

Yu, X., Y. Yana, \& W. Wang. 2011. The distribution and speciation of trace metals in surface sediments from the Pearl River Estuary and the Daya Bay, Southern China. Marine Pollution Bulletin, 60: 1364-1371. https://doi.org/10.1016/j.marpolbul.20 10.05.012

Zainal, A. \& F. Diani. 2009. Fraksinasi logam berat $\mathrm{Pb}, \mathrm{Cd}, \mathrm{Cu}$ dan $\mathrm{Zn}$ dalam sedimen dan bioavailabilitasnya bagi biota di perairan Teluk Jakarta. Ilmu Kelautan, 14(1): 27-32.

https://doi.org/10.14710/ik.ijms.14.1.2 7-32

Zhao, S., C. Feng, W. Quan, X. Chen, J. Niu, \& Z. Shen. 2012. Role of living environments in the accumulation characteristics of heavy metals in fishes and crabs in the Yangtze River 
Konsentrasi dan Status Mutu Logam Berat dalam Air dan Sedimen ...

Estuary, China. Marine Pollution Received : 06 October 2017

Bulletin, 64: 1163-1171.

Reviewed : 17 April 2018

https://doi.org/10.1016/j.marpolbul.20 Accepted : 18 April 2021

12.03.023 